\title{
$20 \mathrm{~cm}$ 超の乳腺間質肉腫の 1 例
}

東神戸病院外科 ${ }^{1)}$, 神戸協同病院中央検査科病理 ${ }^{2)}$

鶴 原 知子1 ${ }^{1)}$ 智 宏 ${ }^{1)}$ 菅本 常 夫 ${ }^{11}$ 湧谷 純 ${ }^{2)}$

症例は60歳，女性。約 4 カ月で急速増大した右乳腺腫瘤を主訴に当科受診。来院時の 腫瘍径は $24 \mathrm{~cm}$ で, 肉眼所見・MRI・CT より悪性葉状腫瘍を疑い乳房切除術を施行した。 術前検査にて所属リンパ節の腫大は認めず，間葉系腫場でのリンパ節転移の頻度は少な いため腋窩郭清は行わなかった。永久病理標本では，免疫染色により多方向への分化傾 向を示す間質肉腫と診断された。乳腺の間質肉腫の報告はまれであり，未知の部分も多 い. 今回, $20 \mathrm{~cm}$ 超の乳腺間質肉腫を切除後, 局所含め再発兆候を認めず 3 年を経過した 症例を経験したので，若干の文献的考察を加えて報告する.

索引用語：乳腺，間質肉腫，巨大腫瘍

\section{緒言}

乳腺間質肉腫は，乳腺に特有な軟部肉腫で，術後補 助療法や放射線療法が確立されておらず，術後早期に 再発し，急速に進行して予後不良の経過をとることも 多い.

今回，われわれは術後 3 年再発なく経過を見ること ができた巨大間質肉腫の 1 例を経験したので若干の文 献的考察を加えて報告する。

\section{症例}

患者：60歳, 女性.

主訴：右乳房腫瘤.

既往歴：特記事項なし。

家族歴：母 乳癌.

現病歴：2007年秋頃より右乳房 B 領域に小腫瘤を 自覚していたが,病院に受診する勇気がなく放置. 2008 年 3 月頃より急速増大し，右乳房の変形をきたし人目 より隠せなくなったため，7月に当科を受診した。

初診時現症：右乳房全体を占める $24 \mathrm{~cm}$ 径腫瘤を認 めた (Fig. 1). 乳房下方・外側半分の皮膚は檏血し色 調変化していた。胸壁との可動性はあり，皮膚との可 動性は色調変化した部位を中心に一部不可能であっ た。所属リンパ節は触知しなかった。

乳腺超音波検査（Fig. 2)：右乳房全体を占める，隔

2011年12月20日受付２012年 1月11日採用

〈所属施設住所〉

７658-0051 神戸市東灘区住吉本町 1 - 24-13
壁構造を持つ内部比較的均一な充実性の腫瘤を認め た。一部で出血壊死巣と考えられる, 高エコ一部を伴 う fluid collection を認めた。

胸腹部造影 CT 所見 (Fig. 3) : 右乳房全体を占め る,内部不均一に造影される境界明瞭な腫瘍を認めた。 胸壁との境界は保たれているが，皮膚には浸潤により 固着しているものと考えられた.所属リンパ節の腫大, 肺・肝転移は認めなかった。

乳房造影 MRI 所見：T1T2いずれも不均一な信号 強度を持ち, 内部が多房状充実性の境界明瞭な腫瘍と して認められた，造影効果も多彩で，隔壁構造を持つ 全体的に淡く造影効果のある腫瘤であるが，一部結節 様に早期相より造影効果を認める部位や，壊死と考え られる造影効果のない部位が混在していた。

手術所見：視触診および CT・MRI より悪性葉状腫 瘍を疑い，浸潤性乳癌の可能性はほほ否定的と考えら れた。本来であれば，針生検などで診断をつけるべき であったが，ご本人が拒否されたこと，術前化学療法 などの前にまず切除を希望されていたこと，文献上は 確認できないが侵襲処置による血行性転移のリスクを 考慮するようにとの古典的な考え方もあったことか ら，術前の穿刺吸引細胞診や針生検は施行せず，手術 施行とした。

2008年 7 月，全身麻酔下に右乳房切除術を施行. 術 前 CT・超音波検査にてリンパ節の腫大を認めなかっ たため，腋窩リンパ節郭清は行わなかった．術中所見 では胸壁浸潤は伴わず，直上皮膚も充分に切除するこ 


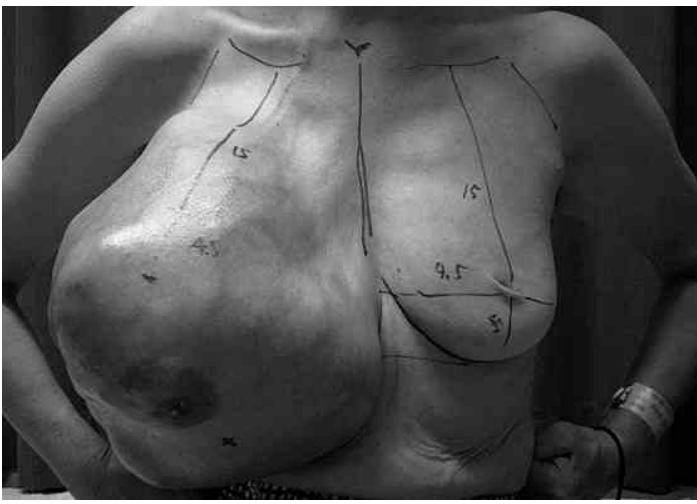

Fig. 1. Physical findings on admission: Right breast was occupied by a giant tumor.

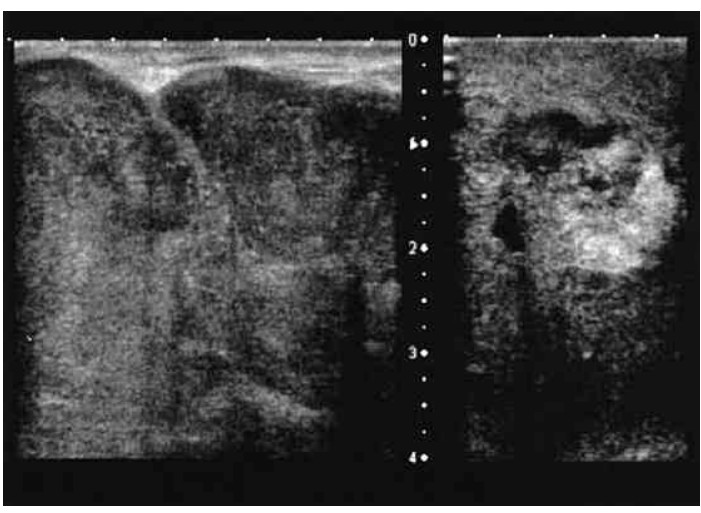

Fig. 2. Ultrasonograph (US) shows a solid tumor with partition structure, partially composed of necrosis and hemorrhage.

とで, 病変部の完全切除が可能であった。

摘出標本肉眼所見 (Fig. 4)：標本の大きさは $24 \times$ $26 \mathrm{~cm}$, 腫場の大きさは $22 \times 24 \mathrm{~cm}$ で重量は $3,780 \mathrm{~g}$ であった。 割面は白色粘液調で,一部に出血や壊死巣を認めた。

病理組織学的検査所見：紡鍾形細胞が腫瘍の主体を 占め，束状配列を呈していた。導管は欠いており，腫 瘍細胞は多形性に富み，細胞境界は不明瞭であった。 細胞成分に富む部位では，Herring bone structure を 模式する fibrosarcoma 様を示し Mitosisを多く認 め, 高悪性度と考えられた，細胞密度が低い部位では 間質が粘液腫を示していた（Fig.5)。免疫染色では， Vimentin が強陽性を示し，一部に CD-34・ $\alpha$ SMA が 染色されており多方向への分化を示していたＡE1/ AE3，S100蛋白は陰性であった (Fig. 6)。上上り間 質肉腫と診断された. Estrogen Receptor, Progester-

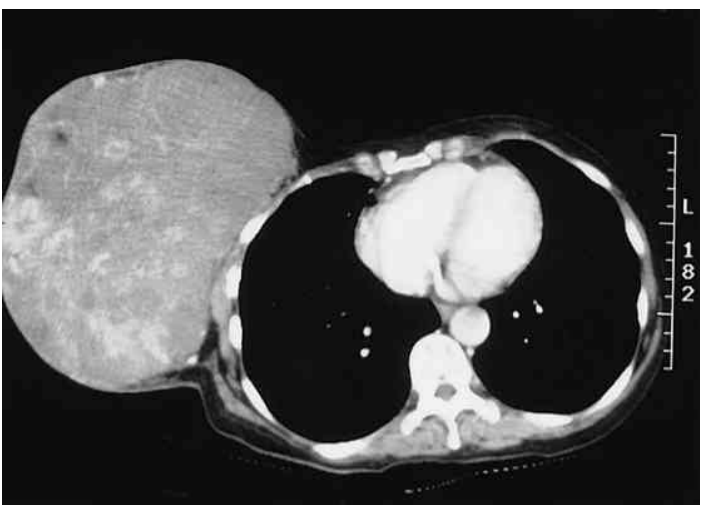

Fig. 3. Enhanced CT scan shows a giant mass with many partial inflow of radiocontrast.

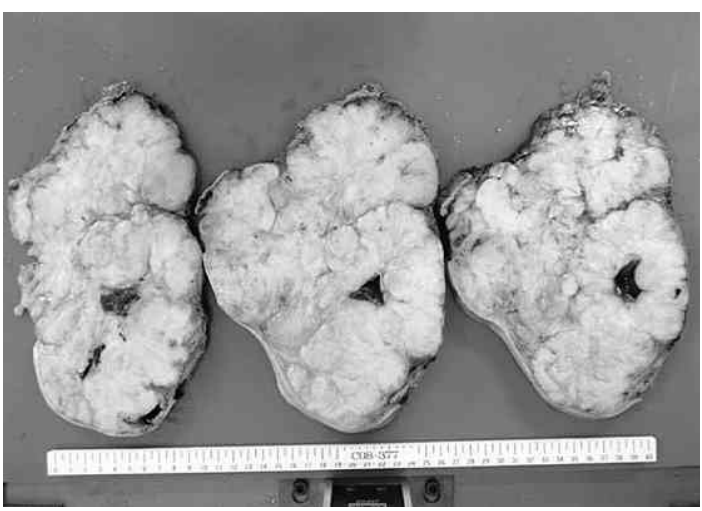

Fig. 4. Pathological findings (Macroscopic findings): Resected specimen was elastic hard tumor with hemorrhage and necrotic component.

one Receptor，HER2はいずれも陰性であった.

術後経過：術後経過は順調で，術後 6 病日に退院と なった，外来で経過観察へ移行した。補助療法は，肉 腫化学療法としてビンクリスチン・ドキソルビシン・ シクロフォスファミド・ダカルバジン・イフォスミド のいずれかの組み合わせが考えられるが，施設により 組み合わせが違うのが現状である。最終的に通常型乳 癌に準じてCAF6コース（シクロフォスファミド500 $\mathrm{mg} / \mathrm{m}^{2}$ ，アドリアマイシン $50 \mathrm{mg} / \mathrm{m}^{2} ， 5-\mathrm{FU} 500 \mathrm{mg} /$ $\mathrm{m}^{2}$ )（ドキソルビシンと同系統薬のアドリアマイシン, シクロフォスファミドが用いられるため効果が期待で きるかと考えた), パクリタキセル $80 \mathrm{mg} / \mathrm{m}^{2}$ 毎週投与 4 コース（計12回）施行した。現在，術後約 3 年を経 過するが，局所再発・遠隔転移などの兆候を認めてい ない. 


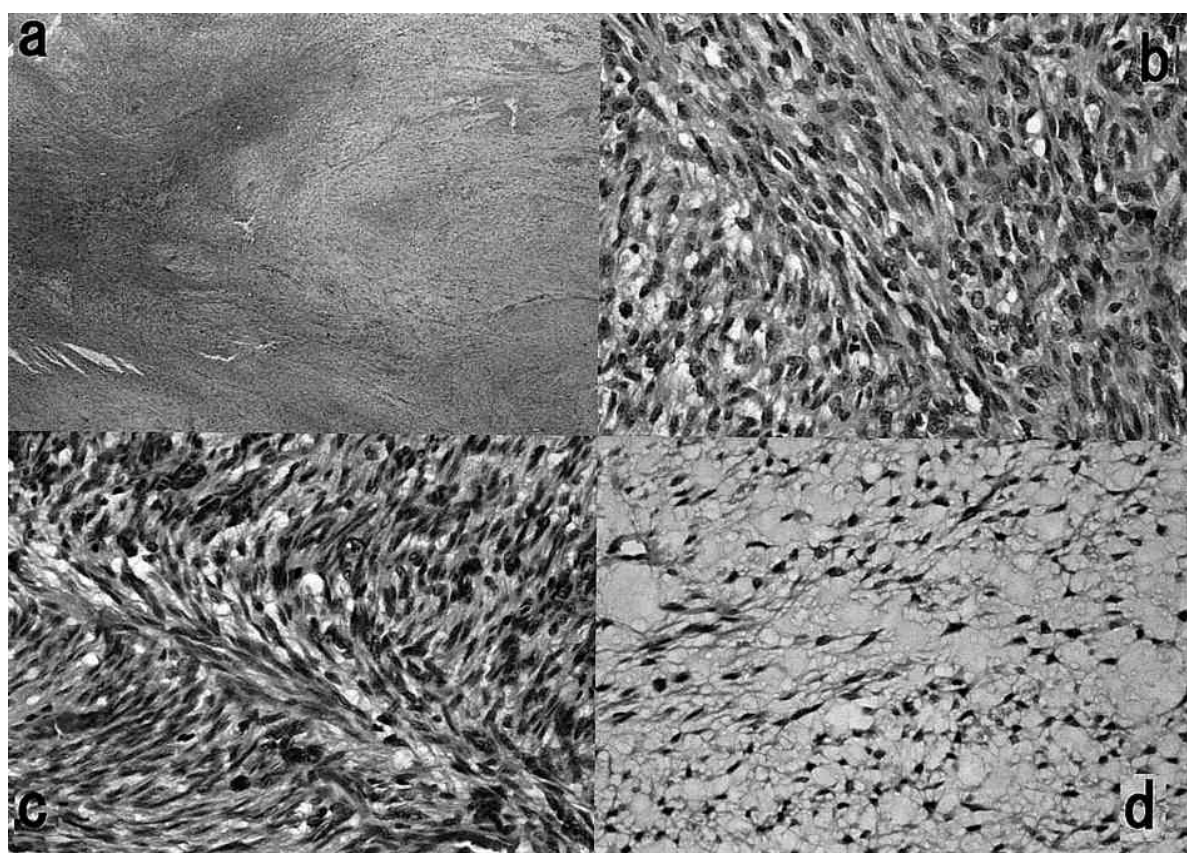

Fig. 5. Pathological findings (H.E. staining) :

a. The tumor was mainly composed of spindle like cells $(\times 40)$.

b. Same as the above $(\times 400)$.

c. Herring bone structure $(\times 400)$.

d. Mucinous compartment $(\times 400)$.

考 察

1962年 Berg ら ${ }^{1)}$ にり提唱された間質肉腫の概念 は，悪性葉状腫瘍・悪性リンパ腫・血管肉腫を除いた 乳腺肉腫を示すものであった. 1977年 Barnes ら²)の分 類では，乳腺肉腫を悪性葉状腫瘍，覀性リンパ腫，間 質肉腫と分類し，間質肉腫の亜分類として純粋型，混 合型，分類不能型とし，さらに純粋型として特定の組 織型への分化を示すものとして血管肉腫・平滑筋肉腫 など11種類の各肉腫の名称を用いることになってい る。現在では，実際には肉腫の成分が主眼に置かれ， 肉腫成分に分けての検討が多い. 欧米とややニュアン スが異なる分類であるが，本邦で発行されている臨 床・病理 乳癌取扱い規約第16版では，非上皮性腫瘍 のなかで軟部腫瘍とは別枠となっており,「悪性葉状腫 瘍の上皮性分がないもの」と定義されている，線維肉 腫や悪性線維性組織球症，脂肪肉腫，軟骨肉腫など各 肉腫成分を含む場合が多いため，悪性葉状腫瘍または 間質肉腫と関係なく生じた場合のみ各肉腫の名称で分 類し，悪性葉状腫瘍あるいは間質肉腫の成分が混在す る場合は，悪性葉状腫瘍または間質肉腫としてまず分
類した上でそれぞれの肉腫の像を付記することとなっ ている ${ }^{3)}$ つまり，Barnes のいう純粋型は，本邦での 間質肉腫とは別の分類となることになる。今回の症例 では，多方向への分化を示す「間質肉腫」としての診 断のほうが，理解しやすいものであった。

発生頻度に関しては，国外の報告では肉腫全体とし ての頻度の報告が多く，日本との比較は困難と思われ る. 本邦において，最も母集団の多いデータとして， 2009年次の全国乳がん患者登録調査報告（暫定）を参 照したところ, 33,675 症例中 16 例で $0.1 \%$ と報告されて いる ${ }^{4)}$. 1984年以降2010年までの原著論文による報告 数は，48例であった. 発症年齢は16-77歳 (平均52.0歳) で，記載内容があるもので集計すると，初診時の腫瘍 最大径は $1.4-30 \mathrm{~cm}$ (平均 $8.1 \mathrm{~cm}$ ) で $10 \mathrm{~cm}$ 以上 $29.2 \%$, $20 \mathrm{~cm}$ 以上が $8.3 \%$ であった。急速増大例は $56.3 \%$ で, 出血壊死を示すものが多かった。

細胞診による術前診断は困難で, 施行された症例の うち 3 割で悪性疑いとなっているが，間質肉腫と診断 がついたものはまれであるため，組織診が必要と考え られる。 


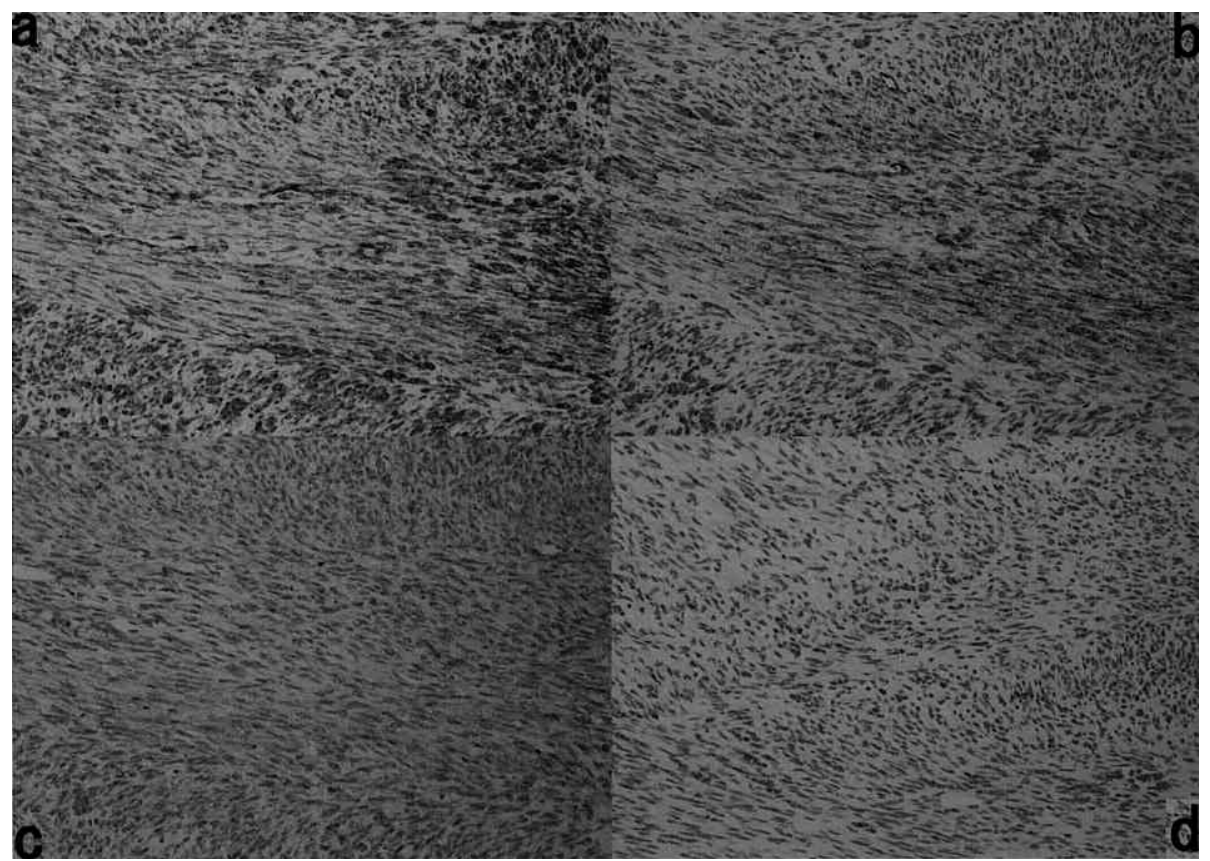

Fig. 6 Pathological findings (Immunostaining)

a Vimentin $(\times 100)$.

b $\mathrm{CD}-34(\times 100)$.

c $\alpha$-SMA $(\times 100)$.

d $\mathrm{AE} 1 / \mathrm{AE} 3(\times 100)$.

乳房切除の是非については, 局所再発を防止するた めに断端距離をとることが重要で, 腫瘍径が大きいか らといって局所再発が増えるわけではなく, 腫瘍径 3 $\mathrm{cm}$ 以下の症例では温存手術が可能であるという露木 らの報告 ${ }^{5)}$ に対し, 所らは局所再発が温存手術14例中 5 例に認められ，乳房切除を行った 51 例中 3 例に認め られたという調查から，乳房切除が望ましいと報告し ている ${ }^{6}$ が,これを結論づけるには, 温存術を行った症 例の腫瘍径や断端距離との関係を評価できるデータべ 一スが必要と考えられる。放射線治療や術後補助療法 が確立していない以上，現時点では，温存手術に対し ては，慎重な判断が必要と考えられる。

再発形式は血行性転移・局所再発が主でリンパ節転 移はまれであるが，腋窩リンパ節への転移報告も認め

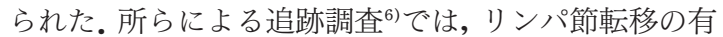
無の記載のあるもの30例のうち 3 例に転移陽性として いるが，詳細をみたところ全例他臟器転移を合併して おり, 初発時に乳房のみの病変であれば，腋窩リンパ 節転移の可能性は低いと考元て良いと思われる。
補助療法は確立されておらず，5 年生存率は我が国 では $47.8 \%$ との報告があり ${ }^{6)}$, 遠隔転移のある症例で はきわめて悪い. 欧米では, 乳腺肉腫全体として 5 年 生存率が50-60\%台と報告しているものが多い.再発が 比較的早く, 再発症例の半数が 2 年目までに認められ, その後再発率が減少する傾向がある7) 99.

今回の症例では, $20 \mathrm{~cm}$ 超の腫瘍で 3 年間無再発生 存が確認された。本邦での報告48症例での, 経過観察 期間の記載があるものを検討してみたところ， 2 年末 満のものが多く, 3 年以上の経過を見たものは 4 例で, 3 例は他臟器転移にて死亡， 1 例のみが 5 年間の無再 発生存が確認されている ${ }^{10) ~ 13)}$. $20 \mathrm{~cm}$ 超の症例は含ま れていない。逆に， $25 \mathrm{~cm}$ 超の原発巣の報告は 4 例(6)14) 16)で，いずれも 1 年以内に転移再発により死亡 されており，3 年の生存例の報告はなかった。

再発症例に対する治療であるが，過去にはシクロフ オスファミドの有効例が報告されていた ${ }^{10)}$ が，治療法 として確立するには至らなかった。他に, CAF, VCR, DTIC を用いた症例もある.最近では, Sueta ら ${ }^{17)} に よ$ 
り，ドキソルビシンとイフォスミドの有効例が報告さ ている。補助療法は絶対数が少なくまだ確立しておら ず，今後症例を蓄積し，術後経過の集積を行った検討 が望まれる.

\section{結語}

$20 \mathrm{~cm}$ 超の乳腺間質肉腫の 1 例を経験したので報告 した。化学療法に関しては，over treatment である可 能性はあるが，術後 3 年再発所見がなく，巨大腫瘍で も長期生存が望める可能性が示唆された。

\section{文献}

1) Berg JW, DeCrosse JJ, Fracchia AA, et al: Stromal sarcomas of the breast. A unified approach to connective tissue sarcomas other than cystosarcoma phyllodes. Cancer $1962 ; 15$ : 418-424

2) Barnes L, Pietruszka M:Sarcomas of the breast:a clinicopathologic analysis of ten cases. Cancer $1977 ; 40: 1577-1585$

3）日本乳癌学会編：乳癌取扱い規約. 第16版，金原 出版, 東京, 2008, p26-27

4）日本乳癌学会編：全国乳がん患者登録調查報告第 40 号2009年次症例, (Accessed October 1，2011， at http://www.jbcs.gr.jp/member_o/member/ 2009zantei.pdf)

5）露木 茂，筒井理仁，島袋 隆他：乳腺間質肉腫 の 1 例と本邦報告101例の再発に関する検討.日臨 外会誌 $2004 ； 65 ： 2863-2867$

6）所知加子, 藤沢 順, 清水 哲他：急速に増大し た乳腺間質肉腫の 1 例と本邦報告例の追加調查後
の集計結果. 乳癌の臨 $2001 ; 16 ： 647-653$

7) Voutsadakis IA, Zaman K, Leyvraz S : Breast sarcomas:Current and future perspectives. Breast $2011 ; 20: 199-204$

8) Confavreux C, Lurkin A, Mitton N, et al: Sarcomas and malignant phyllodes tumours of the breast-a retrospective study. Eur J Cancer 2006 ; $42: 2715-2721$

9) Grenier J, Delbaldo C, Zelek L, et al : Phyllodes tumors and breast sarcomas: a review. Bull Cancer $2010 ; 97: 1197-1207$

10）藤田正弘，朝倉靖夫，田村英嗣他：乳腺再発性間 質肉腫に化学療法の著効した 1 例. 函館医誌 $1987 ； 11 ： 97-100$

11）岡崎 誠, 平井健清, 藤本憲一他：腸重積で再発 した乳腺間質肉腫の 1 例. 乳癌の臨 $1996 ; 11$ ： 607-610

12）川野 亮, 玉田隆一郎，保田浩平他：乳腺間質肉 腫の 1 例. 広島医 $2001 ; 54: 54-57$

13）平野 誠, 宇野雄祐, 村上 望他: 乳腺間質肉腫 の 1 例. 乳癌の臨 $2000 ; 15: 222-225$

14）栗原照昌，野本親男，未盛公人他：乳腺間質肉腫 の 1 例. 埼玉医会誌 $1992 ； 27 ： 139-142$

15）小山英之，石原明徳，上森 昭他：乳腺間質肉腫 の 1 例. 日臨細胞会誌 $2001 ； 40 ： 226-227$

16）新保雅也，仲本 剛，牧本伸一郎他：巨大乳腺間 質肉腫の 1 例。臨外 $2001 ; 56: 267-269$

17) Sueta $A$, Yamamoto $Y$, Inoue $K$, et al : Stromal sarcoma of the breast with lung metastases showing a clinical complete response to doxorubicin plus ifosfamide treatment: report of a case. Surg Today $2011 ; 41: 1145-1149$

\title{
AN OVER 20-cm SIZED GIANT STROMAL SARCOMA OF THE BREAST - REPORT OF A CASE-
}

\author{
Tomoko TSURUHARA ${ }^{1)}$, Toshihiro SHIN ${ }^{1)}$, Tsuneo SUGAMOTO ${ }^{1)}$ and Jun WAKUYA ${ }^{2)}$ \\ Department of Surgery, Higashi Kobe Hospital ${ }^{1)}$ \\ Division of Pathology, Central Clinical Laboratory, Kobe Kyodo Hospital ${ }^{2)}$
}

A 60-year-old woman was seen at the hospital because of a right breast mass enlarged rapidly during these four months. The mass was $24 \mathrm{~cm}$ in diameter on admission. Malignant phyllodes tumor seemed a likely diagnosis from gross, MRI and CT findings and mastectomy was performed. Since preoperative examinations revealed no regional lymph node swelling and phyllodes tumors are reported to metastasize to lymph nodes in a low frequency, axillary lymph node dissection was not done. From immunohistochemistry of the permanent pathological specimen, stromal sarcoma showing differentiating tendency into various directions was diagnosed.

Stromal sarcoma of the breast is a rare entity and most clinicopathological behavious of the tumor have been still unknown. We herein report a patient with an over $20-\mathrm{cm}$ sized stromal sarcoma of the breast who has been free from any recurrences including local recurrence as of three years after the operation, with some bibliographic comments.

Key words : breast, stromal sarcoma, giant tumor 